\title{
The Green Journey
}

\author{
Sourav Haldar • Amitabha Chattopadhyay
}

Published online: 23 December 2008

(C) Springer Science + Business Media, LLC 2009

These are exciting times for fluorescence spectroscopists as the 2008 Nobel prize in Chemistry is awarded for the discovery and development of the Green Fluorescent Protein (GFP) to Osamu Shimomura, Martin Chalfie and Roger Tsien. In a relatively short span of time, GFP and its variants have become extremely popular reporter molecules for monitoring gene expression, localization, mobility, traffic and interaction of various membrane and cytoplasmic proteins. GFP possesses characteristics that are highly desirable for use as a reporter molecule [1]. These include its intrinsic, cofactor-independent fluorescence which exhibits remarkable stability in the presence of denaturants and over a wide range of $\mathrm{pH}$.

The green journey began with Osamu Shimomura in 1962 with the jellyfish Aequorea victoria whose outer edge glows green when the jellyfish is agitated. Although Shimomura initially isolated a blue luminescent protein (termed 'aequorin') [2], it later became clear that the green

S. Haldar $\cdot$ A. Chattopadhyay $(\bowtie)$

Centre for Cellular and Molecular Biology,

Hyderabad, India

e-mail: amit@ccmb.res.in glow of the jellyfish is due to the presence of an inherently fluorescent protein, later termed as green fluorescent protein. Two major developments in the early 1990's dramatically changed the course of future GFP research and revolutionized modern cell biology: (i) Cloning of the gene that encodes GFP by Douglas Prasher, Franklyn Prendergast and co-workers [3]; and (ii) successful demonstration by Martin Chalfie, Douglas Prasher and co-workers that GFP could be expressed in heterologous systems such as E. coli and C. elegans [4]. The uniqueness of the latter approach was that no exogenous substance or cofactor was found to be necessary for GFP fluorescence. GFP therefore made life visible, albeit in a green way ! GFP is a compact barrel-shaped protein of 238 amino acids made of $11 \beta$ strands with an $\alpha$ helix running through the central axis of the cylindrical structure and can be viewed as a molecular lantern. Roger Tsien and co-workers subsequently showed that the $\alpha$ helix contains the fluorophore of GFP responsible for its green fluorescence at the center of the cylindrical structure and is formed spontaneously upon folding of the polypeptide chain by internal cyclization and oxidation of the residues Ser65Tyr66-Gly67. Interestingly, the fluorophore is in a highly constrained environment, protected from the bulk solvent by the surrounding $\beta$ strands [5], as shown by dipolar relaxation measurements [6]. Roger Tsien's work further broadened this area of research when he developed GFP derivatives with improved spectral characteristics and photostability. The complex photophysics of GFP presents challenging questions, opening up a fascinating field of research [7]. GFP turns out to be a bright hope in the 'dark' mysteries inside living cells. 


\section{References}

1. Tsien RY (1998) The green fluorescent protein. Annu. Rev. Biochem. 67:509-544

2. Shimomura O, Johnson FH, Saiga Y (1962) Extraction, purification and properties of aequorin, a bioluminescent protein from the luminous hydromedusan, Aequorea. J. Cell. Comp. Physiol. 59:223-239

3. Prasher DC, Eckenrode VK, Ward WW, Prendergast FG, Cormier MJ (1992) Primary structure of the Aequorea victoria greenfluorescent protein. Gene 111:229-233
4. Chalfie M, Tu Y, Euskirchen G, Ward WW, Prasher DC (1994) Green fluorescent protein as a marker for gene expression. Science 263:802-805

5. Ormö M, Cubitt AB, Kallio K, Gross LA, Tsien RY Remington SJ (1996) Crystal structure of the Aequorea victoria green fluorescent protein. Science 273:1392-1395

6. Haldar S, Chattopadhyay A (2007) Dipolar relaxation within the protein matrix of the green fluorescent protein: A red edge excitation shift study. J. Phys. Chem. B 111:14436-14439

7. Chattoraj M, King BA, Bublitz G, Boxer SG (1996) Ultra-fast excited state dynamics in green fluorescent protein: multiple states and proton transfer. Proc. Natl. Acad. Sci. U. S. A. 93:8362-8367 